Document downloaded from:

http://hdl.handle.net/10251/74183

This paper must be cited as:

Castells-Sala, C.; Martínez Ramos, C.; Vallés Lluch, A.; Monleón Pradas, M.; Semino, C. (2015). In vitro development of bioimplants made up of elastomeric scaffolds with peptide gel filling seeded with human subcutaneous adipose tissue-derived progenitor cells. Journal of Biomedical Materials Research Part A. 103(11):3419-3430. doi:10.1002/jbm.a.35482.

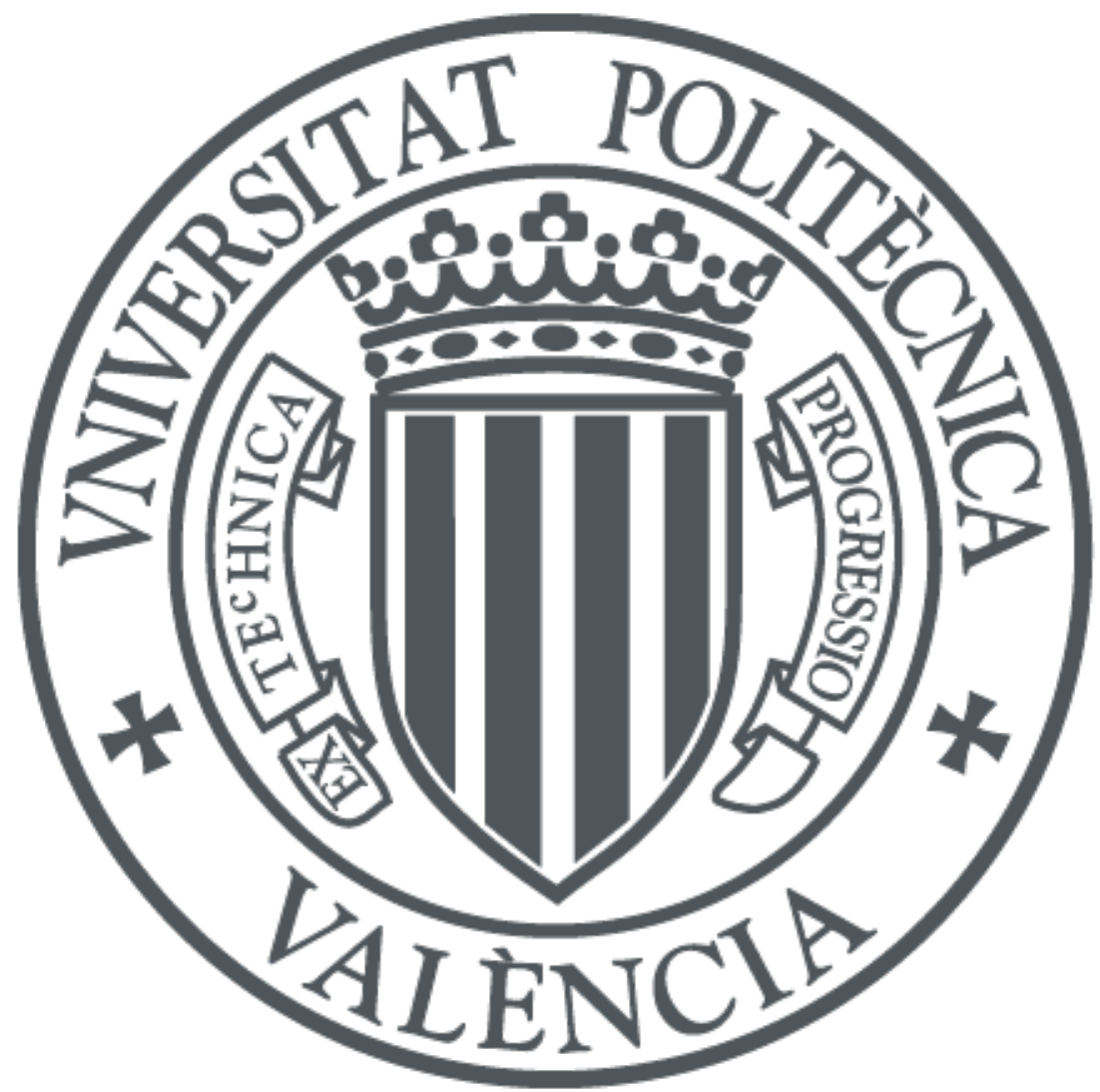

The final publication is available at

http://dx.doi.org/10.1002/jbm.a.35482

Copyright Wiley

Additional Information 


\title{
In vitro development of bioimplants for myocardial infarct made up of elastomeric scaffolds with peptide gel filling seeded with subcutaneous adipose tissue-derived progenitor cells
}

Cristina Castells-Sala ${ }^{1 \#}$, Cristina Martínez-Ramos", Ana Vallés-Lluch ${ }^{2}$, Manuel Monleón Pradas ${ }^{2}$, Carlos Semino ${ }^{1 *}$

(1) Tissue Engineering Laboratory, Bioengineering Department, Institut Químic de Sarrià, Universitat Ramon Llull, Barcelona, Spain

(2) Center for Biomaterials and Tissue Engineering, Universitat Politècnica de Valencia, Cno. de Vera s/n, 46022, Valencia, Spain

\# Cristina Castells-Sala and Cristina Martínez-Ramos contributed equally to this work

* corresponding author. Tel.: +34932672000. E-mail: carlos.semino@iqs.url.edu

\begin{abstract}
Myocardial tissue lacks the ability to regenerate itself significantly following a myocardial infarction. Thus, new strategies that could compensate this lack are of high interest. Cardiac tissue engineering (CTE) strategies are a relatively new approach that aims to compensate the tissue loss using combination of biomaterials, cells and bioactive molecules. The goal of the present study was to evaluate cell survival and growth, seeding capacity and cellular phenotype maintenance of subcutaneous adipose tissue derived progenitor cells (subATDPCs) in a new synthetic biomaterial scaffold platform. Specifically, here we tested the effect of the RAD16-I peptide gel in microporous poly(ethyl acrylate) polymers (PEA) using two-dimensional PEA films as controls. Results showed optimal cell adhesion efficiency and growth in the polymers coated with the self-assembling peptide RAD16-I. Importantly, subATDPCs seeded into microporous PEA scaffolds coated with RAD16-I maintained its phenotype by assessing specific progenitor markers using protein and gene expression analysis. These data suggest that this bioimplant (scaffold/RAD16-I/cells) can be suitable for further in vivo implantation with the aim to improve the function of affected tissue after myocardial infarction.
\end{abstract}

\section{INTRODUCTION}

Tissue or organ damage loss through disease and trauma are one of the most common, harmful and costly problems in human health care. Nowadays, treatment options 
include transplantation, medical devices, surgical reconstructions and in few cases drug therapy. However, these techniques present associated problems and none of them shows a satisfactory long-term recovery [1]. For this reason, Tissue Engineering (TE) emerged as a significant potential alternative or complementary solution that combines scaffolds, cells and/or bioactive molecules with the aim to develop biological substitutes that maintain, improve or restore tissue function [2].

According to the World Health Organization, nowadays myocardial infarction (MI), which results from oxygen insufficiency producing ischemic necrotic tissue, leads to 29 $\%$ of deaths worldwide $[3,4]$. After MI, heart muscle regeneration through biological mechanisms is not enough to compensate the large-scale tissue loss, and cellular therapies appear as a good alternative to the actual treatments. The first attempt of cell therapies was direct cell injection, but it was reported to obtain poor engraftment and viability [5,6]. In this scenario, Cardiac Tissue Engineering (CTE) opens a new approach to address the development of cardiac tissue patches with the aim to increase cell engraftment and viability with the hope to promote the neoformation of functional myocardial tissue. Right now, it is not possible to make a clear statement on CTE efficiency but different in vivo studies have shown encouraging results [7-9], which have led the scientific community to develop and improve new strategies.

Different cell types are under research as potential sources for cardiac cell therapy, including cardiac myocytes, skeletal myoblasts as well as embryonic stem cells (ESCs) and adult stem cells (ASCs). Interesting reviews have been published during the last years referring to this field $[7,8,10]$. In the present study, ASCs have been employed. This kind of cells can be obtained from various tissues including bone marrow $[11,12]$, adipose tissue [12-17], and umbilical cord [18,19]. Their principal advantage is their ease of isolation from the own patient, which decrease the risk of immune response or tumors generation. Specifically, subcutaneous adipose tissue derived progenitor cells (subATDPCs) from cardiac adipose tissue origin were used herein. As cells cannot withstand the mechanical and biophysical extreme conditions experienced in the ischemic heart, we propose to seed the cells in a scaffold in order to obtain a bioactive patch. The scaffold could serve as a carrier and early biomechanical support for implanted subATDPCs [4]. 
Nowadays, different materials in combination or not of different cell types are being tested to improve tissue function. The polymers employed so far, with the aim to obtain these scaffolds, include natural and synthetic polymers. Collagen, gelatin, fibrin, hyaluronic acid and alginate [20,21] from natural origin are widely used. Additionally, synthetic polymers such as poly(ethylene glycol) (PEG), polylactide acid (PLA), polylactide-co-glycolic acid (PLGA), polycaprolactone (PCL) and poly(glycerol sebacate) (PGS) [22,23] with different architectures are under study. Since the heart is an organ of unparalleled complexity with contractile, conductive and vascular systems, the ideal material for CTE should meet a series of requirements [24]. First of all, it should serve as biological, biophysical and mechanical support for cell growth, function and differentiation. The material should closely mimic the heart architecture and allow the remodeling of the extracellular matrix (ECM). Additionally, a proper interaction with the host tissues, promoting rapid vascularization and host macrophage infiltration in order to remove cellular debris is also important. Moreover, due to the continuous expansion and contraction of heart tissue, the material must be stress and strain resistant, but elastic enough to enable contractile forces transmission [4]. All these characteristics are difficult to be achieved with a sole material, and for this reason we propose that a combination of biomaterials could better satisfy the mentioned requisites. Thus, a combination of an elastomeric microporous membrane, poly(ethyl acrylate), PEA [25,26] filled with RAD16-I self-assembling peptide was proposed. PEA elastomeric membrane can satisfy the mechanic and structural requirements of the heart and provide biomechanical support to cells while RAD16-I was added to improve cell colonization and survival within the scaffold [27].

PEA is a synthetic hydrophobic material with excellent biological performance and mechanical properties (elastic and loss moduli) similar to those of soft organic tissues [28]. Interestingly, it has shown good compatibility in vitro and in vivo with different cell types: chondrocytes, osteoblasts, keratocytes, human umbilical vein endothelial cells, neural cells, or dental pulp stem cells [29-32]. Additionally, PEA has been shown to adsorb on its surface ECM adhesion molecules that are amiably recognized by cells $[33,34]$. On the other hand, RAD16-I (more than 99\% water) is used to provide an appropriate microenvironment to the implanted cells. It has been previously reported to promote growth and proliferation of multiple cell types, including chondrocytes, 
hepatocytes, endothelial cells, neuronal cells [35-39], as well as mouse embryonic stem cells and mouse embryonic fibroblasts $[40,41]$.

Therefore, the combination of PEA elastomeric membrane and RAD16-I gel can overcome the shortcomings of both materials. The final aim was to obtain a bioactive implant that can be used as a carrier for cell delivery and promote improvements in cardiac function. This could be achieved by providing structural and nutrient support for transplanted cells survival, better integration with the host tissue, and re-population of injured non-contractile ventricle.

The methodology associated to the combination of these materials and cells was addressed in previous works [42]. In the present work we used these material platform to study the behavior of subATDPCs in terms of cell viability, growth, patch distribution and analysis of early and definitive cardiac markers.

\section{MATERIALS AND METHODS}

\subsection{Preparation of the composites (PEA+RAD16-I)}

Preparation of poly(ethyl acrylate), PEA, scaffolds: Poly(ethyl acrylate) elastomeric scaffolds with interconnected spherical pores were obtained by an ultraviolet polymerization of the monomer mixture and a template leaching technique, following the procedure described in [43,44]. Briefly, ethyl acrylate (99\%, Sigma Aldrich) monomer was mixed with 1 wt $\%$ of benzoin (98\%, Scharlau) as photo-initiator and 2 wt $\%$ of ethylene glycol dimethacrylate (98 \%, Sigma Aldrich) as cross-linker, stirred for $20 \mathrm{~min}$, injected in a porogen template consisting of sintered poly(methyl methacrylate) microspheres of $130 \pm 20 \mu \mathrm{m}$ in diameter (PMMA; Colacryl dp 300), polymerized in a mold, and postcured in an oven at $90{ }^{\circ} \mathrm{C}$ for $24 \mathrm{~h}$. After polymerization, the PMMA templates, as well as residual substances of low molecular weight, were removed by soxhlet extraction with acetone (Scharlab). Next, the solvent was slowly exchanged with water, and the scaffolds were dried under vacuum. Films were obtained by a polymerization of the monomer mixture in a plane glass mold, to be used as controls. The final thickness was $0.8 \mathrm{~mm}$ approximately.

Samples were cut from both the scaffolds and the films as 5 and $8 \mathrm{~mm}$-diameter circles for in vitro assays. Previous to in vitro assays, PEA elastomeric membranes were 
sterilized with a $25 \mathrm{kGy}$ dose of gamma irradiation in a ${ }^{60} \mathrm{Co}$ source (Aragogamma, Barcelona, Spain).

Loading of RAD16-I and characterization of the obtained composite: The selfassembling peptide RAD16-I (PuraMatrix ${ }^{\mathrm{TM}} 1 \%(\mathrm{w} / \mathrm{v})$, BD Biosciences) was used as a filler hydrogel of PEA scaffolds pores [34]. Prior to its use, RAD16-I was sonicated in a Bandelin bath for $30 \mathrm{~min}$ at $25^{\circ} \mathrm{C}$ applying $30 \mathrm{~W}$ in order to decrease its viscosity. Then, it was diluted to $0.15 \%$ (w/v) with water (extra pure, Scharlau) and vortexed (Elmi SkyLine) to ensure homogenization before its loading in the pores of the elastomeric membranes. Each membrane was submerged in a peptide $0.15 \%$ solution and with the help of the vacuum it was forced to penetrate in the voids of the porous structure, displacing the air. The gelling of RAD16-I peptide inside the pores was induced by soaking with phosphate buffer saline (PBS) during $30 \mathrm{~min}$ and assessed in a Hitachi S4800 scanning electron microscopy (SEM) [34]. Bare PEA scaffolds were observed as controls (see Figure 1).

\subsection{Cell expansion and seeding in bare scaffolds and composites}

Cell expansion: Subcutaneous adipose tissue derived progenitor cells (subATDPCs)* were isolated from fat pads between skin and sternum from patients undergoing cardiac surgery and processed as previously described $[45,46]$. Informed consent was obtained from all subjects, and the study protocol conformed to the principles outlined in the Declaration of Helsinki. The extracted adherent cells were expanded in culture plates under standard conditions $\left(37{ }^{\circ} \mathrm{C}\right.$ and $5 \% \mathrm{CO}_{2}$ ) in $\alpha$-MEM (Sigma) supplemented with $10 \%$ fetal bovine serum (Lonza) and $1 \%$ penicillin-streptomycin (Labclinics), $1 \%$ Lglutamine (Labclinics) and $5 \mu \mathrm{g} / \mathrm{mL}$ plasmocin (Invivogen). At the third passage cells of five patients were mixed to obtain a pool. The subsequent experiments were performed at passage eight.

Cell seeding in bare scaffolds and composites: RAD16-I $0.15 \%$ solution was loaded in the pores of PEA scaffolds of the two sizes as explained. Next, samples of $8 \mathrm{~mm}$ diameter were placed in a 48 -well plate and those of $5 \mathrm{~mm}$ diameter were placed in a 96-well plate. In parallel, subATDPCs were trypsinized and divided into two aqueous solutions of final concentrations of 10000 cells $/ \mu \mathrm{L}$ and 5000 cells $/ \mu \mathrm{L}$ with $10 \%$

\footnotetext{
* Kindly provided by Dr. Carolina Soler-Botija from Dr. Antoni Bayés-Genís group, Hospital Germans Trias i Pujol, Badalona (Spain)
} 
sucrose. $50 \mu \mathrm{L}$ of the first suspension was carefully injected inside $8 \mathrm{~mm}$ diameter bare and filled scaffolds for gene and protein profile studies and inside $5 \mathrm{~mm}$ diameter ones for image analyses. The second cell suspension was injected in $5 \mathrm{~mm}$ bare and filled scaffolds for viability studies. After injection, the samples were incubated under soft shaking during $30 \mathrm{~min}$ to allow the cells to migrate slightly into the construct. Finally, $250 \mu \mathrm{L}$ and $150 \mu \mathrm{L}$ of fresh medium were added in each well of the 48-wells and 96wells plate, respectively, allowing the peptide to gel (see Figure 1). Thus, the final cell density was 625 cells $/ \mu \mathrm{L}$ for all samples. Samples were cultured under standard conditions $\left(37^{\circ} \mathrm{C}\right.$ and $\left.5 \% \mathrm{CO}_{2}\right)$ during 1 and 7 days. For cell maintenance half of the culture medium was changed daily. The same procedure was performed with bare scaffolds prefilled with PBS in place of RAD16-I, which were used as controls.

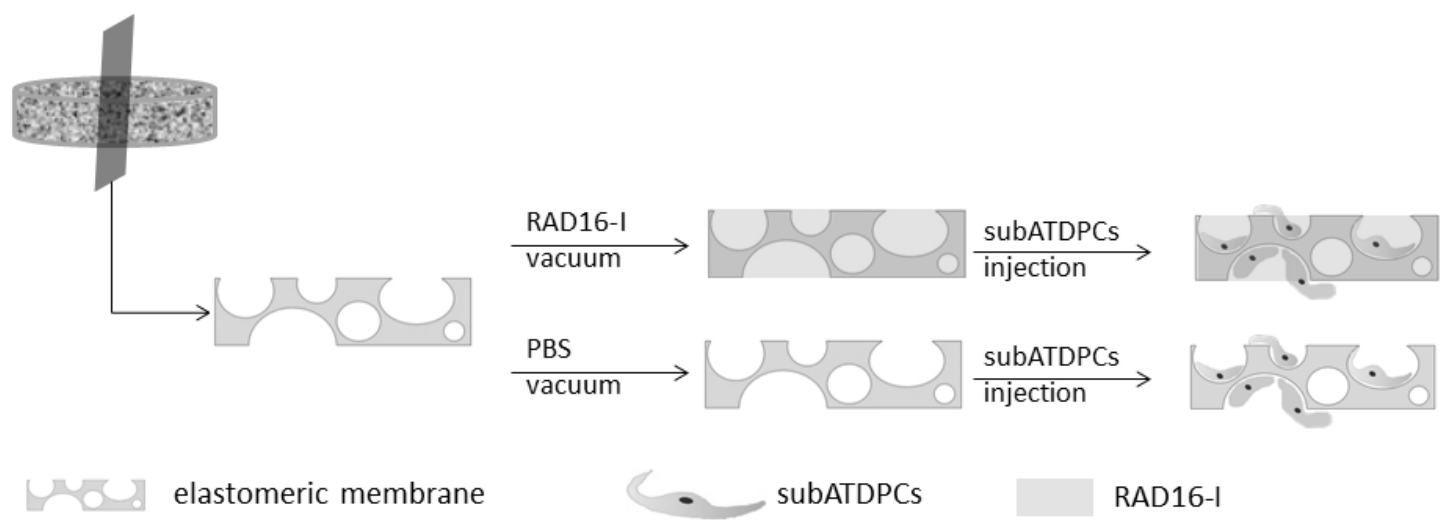

Figure 1: Methodology scheme. PEA elastomeric membranes were polymerized leaving interconnected spherical pores. Here a section of the scaffold is observed. The scaffolds were filled with RAD16-I (composites) or PBS (bare PEA) using vacuum. Finally, subATDPCs were injected inside the scaffolds. Scaffold size and cell number were dependent on the analysis but cell density was maintained $(625$ cells $/ \mu \mathrm{L})$.

\subsection{Cell viability MTT assay}

Cell viability was assessed in $5 \mathrm{~mm}$ diameter scaffolds by the MTT assay according to the manufacturer's instructions. It is based in the reduction of the yellow tetrazolium salt MTT to formazan crystals giving purple color. This reaction only takes place when cellular reductase enzymes are active and, therefore, conversion is often used as a measure of viable cells, referred to his metabolic activity. Briefly, after 1 and 10 days of culture, the media were aspirated, and MTT reagent (Sigma) was added at a final concentration of $0.5 \mathrm{mg} / \mathrm{mL}$ in culture medium. The samples were incubated for 3 hours at $37{ }^{\circ} \mathrm{C}$ in the dark. After this time, formazan crystals were dissolved by soaking the samples in $300 \mu \mathrm{l}$ of dimethylsulfoxide (DMSO) about $10 \mathrm{~min}$. The absorbance was 
read at $550 \mathrm{~nm}$ with a BIOTECH ELX 800 spectrophotometer. Scaffolds without cells were used as negative controls. All samples were analyzed in triplicate.

\subsection{Immunocytochemistry}

The cell morphology and distribution were observed by confocal microscopy in bare scaffolds and composites (bioimplants). After 7 days of culture, the samples were fixed for 20 min with paraformaldehyde (Panreac) at $4 \%$ in phosphate buffer (PB $0.1 \mathrm{M}$ ) and the expression of $\alpha$-actinin (ACTN1) and F-actin was examined.

Briefly, samples were washed with PBS and permeabilized during 60 min with PBSBSA $1 \%$ (PBSA). Next, samples were incubated overnight with monoclonal anti- $\alpha-$ actinin (Sarcomeric) Clone EA-53 (1:100; Sigma) diluted in PBSA, and exposed to secondary antibody (goat anti-mouse 488, 1:200, DakoCytomation) during $1 \mathrm{~h}$ at room temperature. Then, samples were stained with a selective marker for F-actin (Alexa Fluor Phalloidin 647, 1:200; Invitrogen) in PBSA for $2 \mathrm{~h}$ at room temperature. Nuclei were counter-stained with 4',6-diamidino-2-phenylindole (DAPI, 1:5000) for $5 \mathrm{~min}$. Finally, samples were cryoprotected by immersion in $0.1 \mathrm{M}$ PB containing $30 \%$ sucrose during 1 day and included in OCT. Sections of $100 \mu \mathrm{m}$ were obtained using a cryostat (Leica, CM 1900) and examined under a confocal microscopy (Olympus FV1000).

\subsection{Scanning electron microscopy (SEM)}

Cultured samples were treated using standard procedures in order to examine cell morphology and their layout on the surface of the scaffolds by scanning electron microscopy (SEM). Samples were fixed with $2.5 \%$ glutaraldehyde in PB $0.1 \mathrm{M}$ for 60 min at $37^{\circ} \mathrm{C}$. Then, they were treated with $1 \%$ osmium tetraoxide for $2 \mathrm{~h}$, followed by dehydration using increasing concentrations of ethanol every $10 \min \left(30^{\circ}, 50^{\circ}, 70^{\circ}, 96^{\circ}\right.$, $100^{\circ}$ ). Finally, samples were air dried and sputtered with gold before observation in a Hitachi (S-4800) microscope at $15 \mathrm{kV}$. Bare and gel-filled scaffolds were examined for the sake of comparison.

\subsection{Study of gene expression by RT-PCR}

Reverse transcription polymerase chain reaction (RT-PCR) was performed to analyze gene expression in cultured films, bare scaffolds and bioimplants. The samples were lysed, and RNA was extracted with PeqGold Total RNA kit (Peqlab), followed by 
cDNA synthesis with a reverse transcriptase enzyme using Quantitect Reverse Transcription Kit (Qiagen) according to the manufacturer protocol. PCR reaction was carried out using $30 \mathrm{ng}$ of cDNA in a $25 \mu \mathrm{L}$ final volume containing $1 \mathrm{X}$ ThermoPol Reaction Buffer (stock 10X), 0.05 units of TAQ DNA polymerase (Sigma), $200 \mu \mathrm{M}$ of dNTPs (Sigma) and $0.3 \mu \mathrm{M}$ primers (Sigma). The PCR took place under the following conditions: $3 \mathrm{~min}$ at $95{ }^{\circ} \mathrm{C}$ (activation) followed by 35 cycles of $30 \mathrm{~s}$ at $95^{\circ} \mathrm{C}, 20 \mathrm{~s}$ of annealing (Tm dependent on primer pair, see Table 1) and $30 \mathrm{~s}$ at $72^{\circ} \mathrm{C}$. The final extension step was performed at $72{ }^{\circ} \mathrm{C}$ during $15 \mathrm{~min}$. PCR products were sizefractionated by $2 \%$ agarose gel electrophoresis.

\subsection{Study of gene expression by Real Time RT-PCR}

Real Time RT-PCR (qRT-PCR) reactions were performed with LightCycler® 480 RealTime PCR System (Roche), using the $\mathrm{iQ}^{\mathrm{TM}}$ SYBR ${ }^{\circledR}$ Green Supermix (Bio-Rad) as a fluorescent reporter. SYBR® Green binds to double-stranded DNA and upon excitation emits fluorescence. Real-time RT-PCR was run with the following parameters: 1 cycle of 10 minutes at $95{ }^{\circ} \mathrm{C}$ in order to activate the hot-start iTaq ${ }^{\mathrm{TM}}$ DNA polymerase, 50 cycles consisting in 15 seconds at $94{ }^{\circ} \mathrm{C}$ for denaturation of the double stranded cDNA, 15 seconds for primer annealing (Tm dependent on primer pair, see Table 1), and 15 seconds at $72{ }^{\circ} \mathrm{C}$ for extension. Finally melting curve analyses were performed to test the specificity of PCR products, together with agarose electrophoresis. Relative gene fold variations were all determined by the comparative CT method $\left(2^{-\Delta \Delta C t}\right)$ and expression of the target genes was normalized to the housekeeping gene (ribosomal protein 22L, RPL22).

Table 1 Primer pairs used for cardiac markers in RT-PCR. 


\begin{tabular}{|c|c|c|c|c|c|c|}
\hline & NAME & & SEQUENCE & bp & $\operatorname{Tm}(\stackrel{\circ}{ })$ & Fragment \\
\hline \multirow{2}{*}{1} & \multirow{2}{*}{$A C T N 1$} & Fw & GAGAAACTGCTGGAGACCATTGACC & 25 & \multirow{2}{*}{63} & \multirow{2}{*}{$188 \mathrm{bp}$} \\
\hline & & RV & TTGTCGGCATCAGGGAGGGT & 20 & & \\
\hline \multirow{2}{*}{2} & \multirow{2}{*}{ GJA1 } & Fw & \multirow{2}{*}{ comercial QT00012684 } & - & \multirow{2}{*}{55} & \multirow{2}{*}{$92 b p$} \\
\hline & & RV & & - & & \\
\hline \multirow{2}{*}{3} & \multirow{2}{*}{ MEF2C } & Fw & CCATTGGACTCACCAGACCT & 20 & \multirow{2}{*}{65} & \multirow{2}{*}{$139 b p$} \\
\hline & & RV & AGCACACACACACACTGCAA & 20 & & \\
\hline \multirow{2}{*}{4} & \multirow{2}{*}{ MHC } & Fw & TGGGAGATTCGGAGATGGCAGTC & 23 & 64 & $225 b p$ \\
\hline & & RV & CCTGGTCCTCCTTCACGGTCACTG & 24 & & \\
\hline \multirow{2}{*}{5} & \multirow{2}{*}{ NKX2.5 } & Fw & AGTGTGCGTCTGCCTITCCC & 20 & 63 & $250 \mathrm{bp}$ \\
\hline & & RV & AGGTACCGCTGCTGCTTGAAG & 21 & & \\
\hline \multirow{2}{*}{6} & \multirow{2}{*}{$T B \times 5$} & Fw & CATGGAGACATCACCCAGTG & 20 & \multirow{2}{*}{60} & \multirow{2}{*}{$169 b p$} \\
\hline & & RV & GCAGCTGATGTCCTCTAGGC & 20 & & \\
\hline \multirow{2}{*}{7} & \multirow{2}{*}{ RPL22 } & Fw & TGACATCCGAGGTGCCTITC & 20 & \multirow{2}{*}{60} & \multirow{2}{*}{$101 b p$} \\
\hline & & RV & GTTAGCAACTACGCGCAACC & 20 & & \\
\hline \multirow{2}{*}{8} & \multirow{2}{*}{$c T n T$} & Fw & AGAGGCTGAGACCGAGGAGACCA & 23 & \multirow{2}{*}{64} & \multirow{2}{*}{$207 b p$} \\
\hline & & RV & TGCAACTCATTCAGGTCCTTCTCCA & 25 & & \\
\hline
\end{tabular}

\subsection{Western blotting analysis}

$8 \mathrm{~mm}$ diameter bioimplants were cut in small pieces and lysed with the help of a pestle to crush them using RIPA buffer containing proteinase inhibitor cocktail (Roche). The protein content of the supernatant was determined using a Micro $\mathrm{BCA}^{\mathrm{TM}}$ Protein assay kit (Pierce-Thermo Scientific). Equal amounts of total protein $(5 \mu \mathrm{g})$ were separated by electrophoresis on $10 \%$ SDS-PAGE gels at $150 \mathrm{~V}$ during $1 \mathrm{~h} 30 \mathrm{~min}$. Subsequently, the proteins were transferred using wet transference on PVDF membranes (Invitrogen) during $2 \mathrm{~h}$ at $40 \mathrm{~V}$. The PVDF membranes were blocked with $5 \%$ milk buffer during 2 $\mathrm{h}$ at room temperature. The membranes were incubated with rabbit polyclonal antiGATA4 (sc-9053, Santa Cruz), rabbit polyclonal anti-GJA1 (sc-9059, Santa Cruz) and rabbit polyclonal anti-TBX5 (sc-48782, Santa Cruz) at room temperature during $1 \mathrm{~h}$. After 3 washes with PBST (Phosphate Buffered Saline (Gibco; 18912-014) complemented with Tween-20 (Sigma; P-1379)) and an overnight PBST wash, the blots were incubated with peroxidase-conjugated to rabbit IgG goat polyclonal secondary antibody (ab97051, Abcam). The protein bands were detected after incubation with SuperSignal ${ }^{\circledR}$ West Pico Chemiluminescent Substrate (34080, Thermo Scientific) using ImageQuant LAS 4000 mini equipment. Goat polyclonal anti-Actin antibody (sc-1615, Santa Cruz) was used to normalize with peroxidase-conjugated to goat IgG rabbit polyclonal as secondary antibody (ab97100, Abcam). 


\subsection{Statistical analysis}

GraphPad was used for all statistical analyses. The results are given as mean \pm standard deviation as obtained of three independent experiments per group. Comparison of means was performed by two-way analysis of variance with Bonferroni's posttest. Comparison of assays was made by correlation and linear regression analysis. Differences were considered significant if $\mathrm{p}$-value $<0.05$. 


\section{RESULTS}

\subsection{Characterization of bare PEA scaffolds and composites}

The RAD16-I peptide solution was successfully loaded and gelled inside the PEA scaffolds' pores using the protocol described previously by Vallés-Lluch et al. [34]. The obtaining of the desired composites was confirmed by SEM imaging (Figure 2). As it can be observed, the loaded self-assembling peptide solution gives rise to a nanofiber network distributed all along the PEA scaffold pore. This nanofiber structure does not appear when scaffolds are loaded with PBS instead (image not shown).
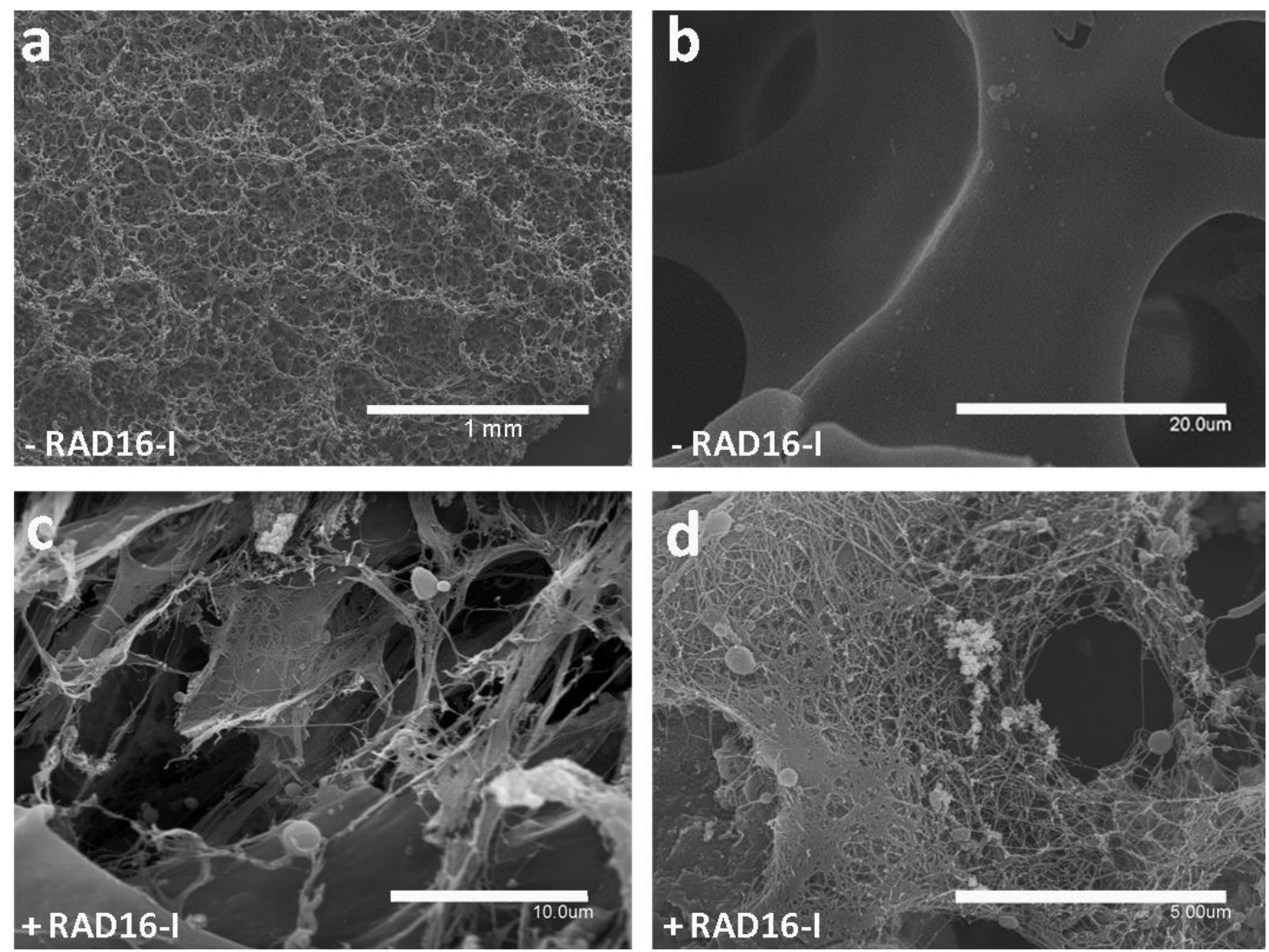

Figure 2: Assessment of composite formation. SEM images of surface (a) and sections of bare (b) and RAD16-I filled PEA scaffolds (c). (d) Detail of RAD16-I nanofibers. Scale bare: $1 \mathrm{~mm}$ (a), $20 \mu \mathrm{m}$ (b), $10 \mu \mathrm{m}$ (c), and $5 \mu \mathrm{m}$ (d).

3.2 Viability, growth and distribution of subATDPCs inside bare scaffolds or composites

SubATDPCs' viability inside bare and gel-filled scaffolds was monitored after 1 and 10 days of culture by MTT colorimetric assay (Figure 3). The MTT test revealed that there were no significant differences in terms of viability between cells growing in bare PEA membranes and those cultured in the composites containing the self-assembling peptide RAD16-I (Figure 3a). In both structures, cell growth was observed at the same extent. 
Interestingly, it was noticed that after 10 days of culture a significant fraction of the cells did not remain in the inner pores of the PEA scaffolds migrating outwards to end adhered on the surface of the well (data not shown). This effect was found to be enhanced in the case of the composite with $53 \%$ of the total cells detected on the surface of the well (Figure 3b). Instead, 36\% of seeded cells in bare PEA membranes were detected outside the scaffold. It can also be appreciated in Figure $2 \mathrm{c}$ that the purplish intensity from formazan crystals is stronger in bare scaffolds than in the composites. These results indicate that cell mobilization is enhanced in the case of composites, which suggest it is a good platform to assure cell delivery to the affected tissue.
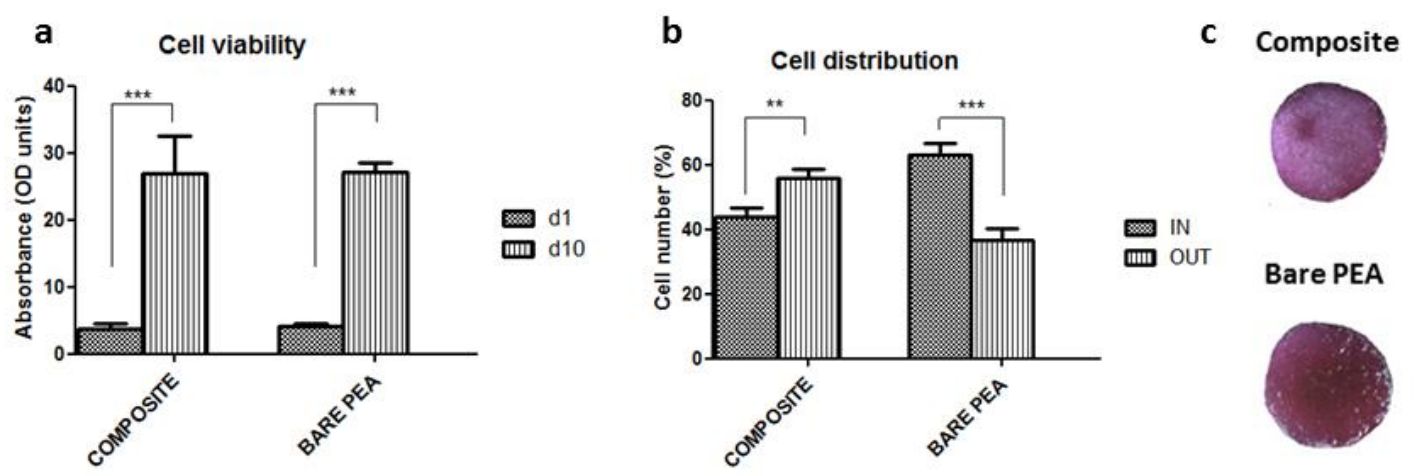

Figure 3: MTT viability assay of subATDPCs growing inside bare PEA scaffolds and composites (PEA scaffold + RAD16-I self-assembling peptide). (a) SubATDPCs proliferation from day 1 to day 10 within both structures. (b) Cell distributions inside the structures and on the culture plate at day 10 of culture. (c) Coloration of both structures owing to the formation of formazan crystals. ( $* * \mathrm{P}<0.01$ and $* * * \mathrm{p}<0.001$ )

\section{3 subATDPCs layout in bare scaffolds or composites}

For the examination of cell distribution in scaffolds, general cell staining with Phalloidin (acting filaments) and DAPI (nuclei) was assessed after 7 days of culture. Composites show much more uniform cell distribution than in bare PEA scaffolds (Figure 4). SubATDPCs display a more elongated morphology around the pores of bare scaffolds, covering the PEA trabeculae as compared to composites where cells show a compact cell network (they are close one to each other and exhibit a spread out morphology). 

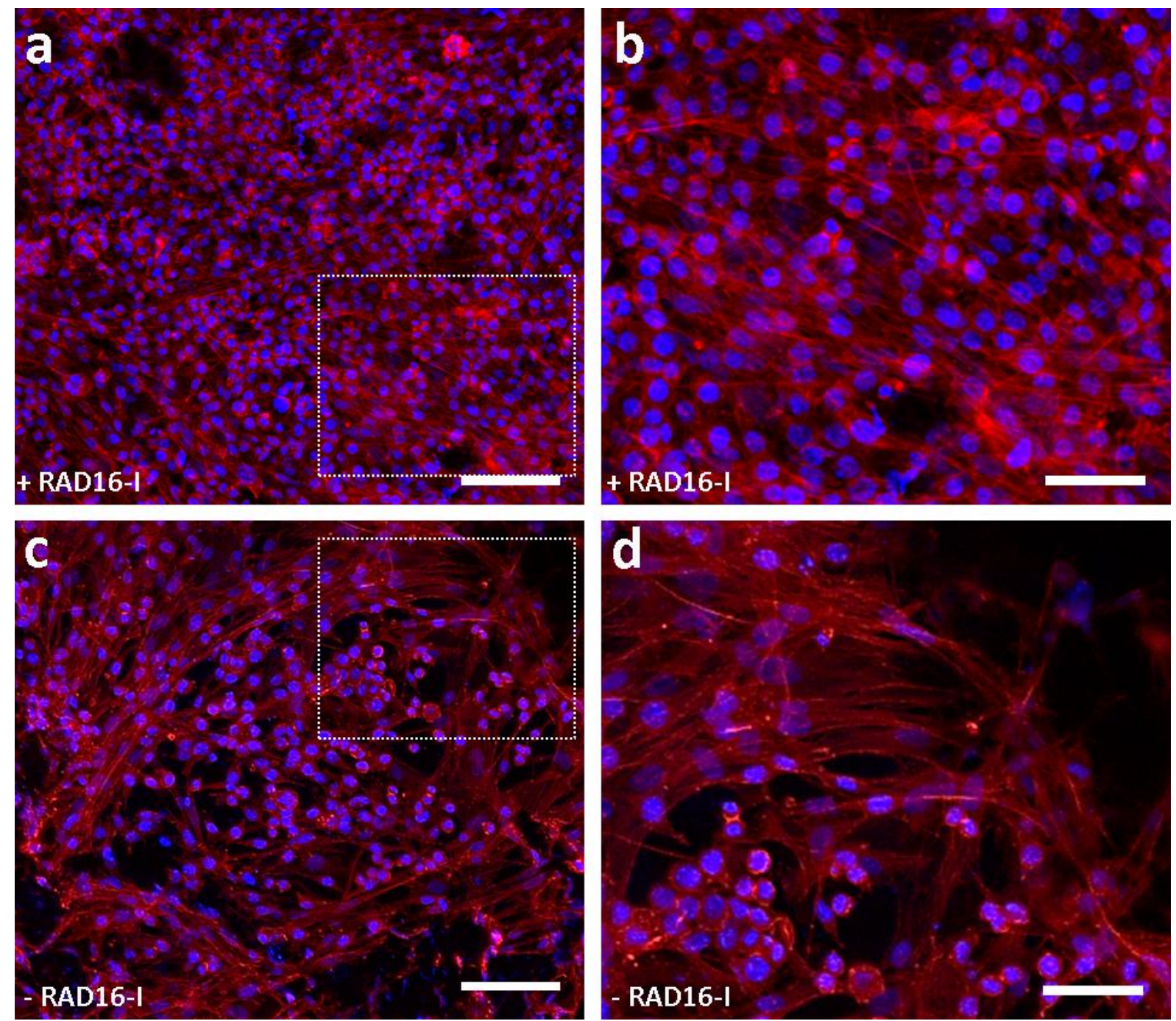

Figure 4: Surface CLSM images of cultured composites and bare PEA scaffolds. Phalloidin (red) staining of subATDPCs growing in the pores of composites ( $a$ and $b$ ) and bare PEA scaffolds ( $c$ and d). DAPI staining for nuclei (blue). Scale bar: $100 \mu \mathrm{m}$ (a and c) and $50 \mu \mathrm{m}$ (b and d).

Samples were also labeled with ACTN1 marker, which recognizes $\alpha$-skeletal muscle actinin and $\alpha$-cardiac muscle actinin (Figure 5). ACTN1 seem to be expressed more homogeneously across the composite than bare PEA scaffolds (Figure 5). 

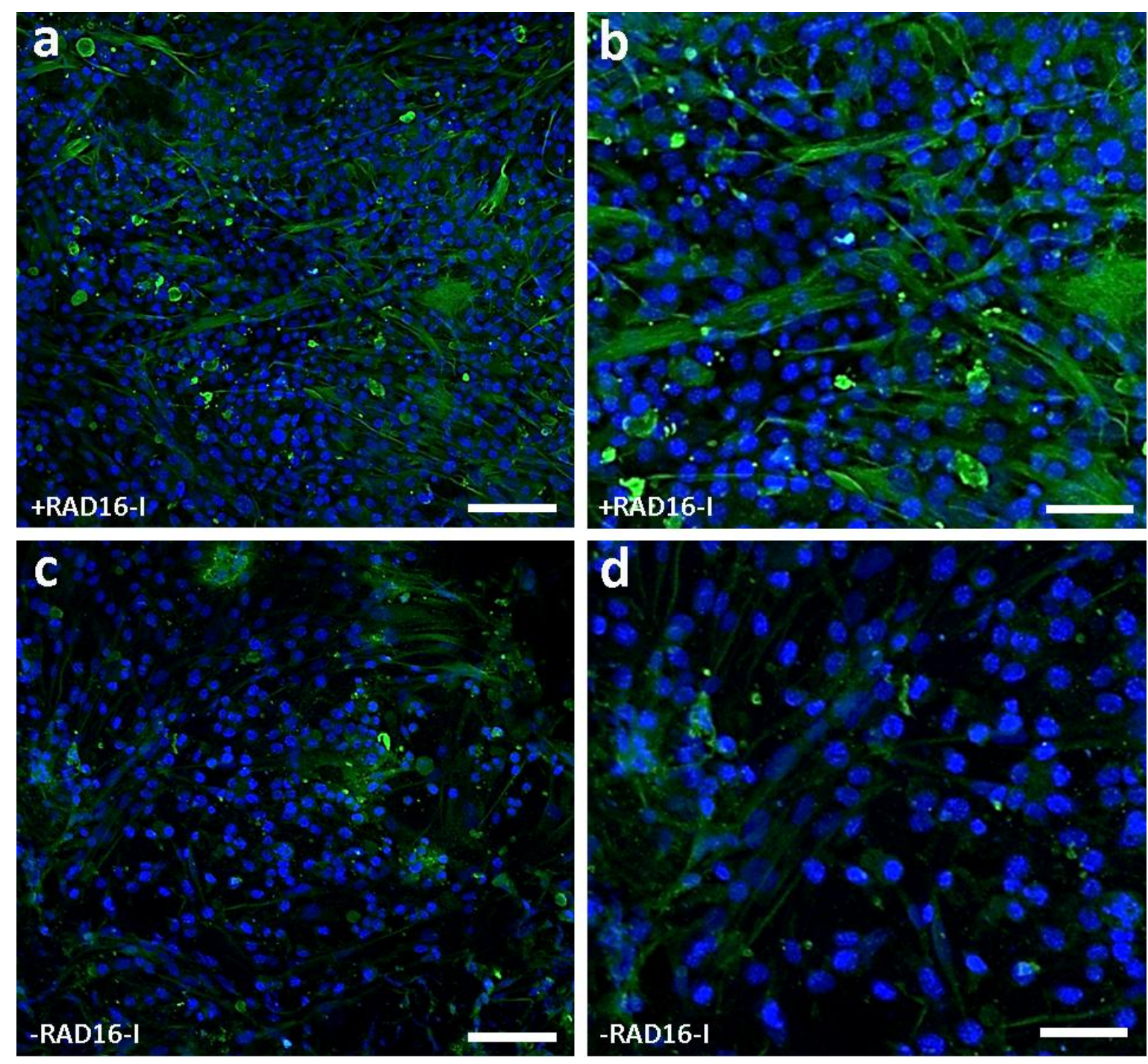

Figure 5: Surface CLSM images of cultured composites and bare PEA scaffolds. ACTN1 (green) staining of subATDPCs growing in pores of composites ( $a$ and b) and bare PEA scaffolds (c and d). DAPI staining for nuclei (blue). Scale bar: $100 \mu \mathrm{m}$ (a and c) and $50 \mu \mathrm{m}$ (b and d).

In both cases, a significant fraction of cells resided on the top of the scaffolds. SEM imaging proved that subATDPCs were able to cover bare PEA and composites' surfaces (Figure 6). Significantly, subATDPCs growing in composites were uniformly distributed covering the surface after 7 days of culture entirely, whereas, on bare PEA scaffolds, a heterogeneous layout was observed. Moreover, subATDPCs cultured on composites' surfaces were organized in a well-ordered pattern, which would facilitate cell-cell contact (Figure 6b). In contrast, subATDPCs growing on bare PEA scaffolds exhibited a disorganized distribution adhered to PEA trabeculae and maintaining pores empty (Figure 6e). 

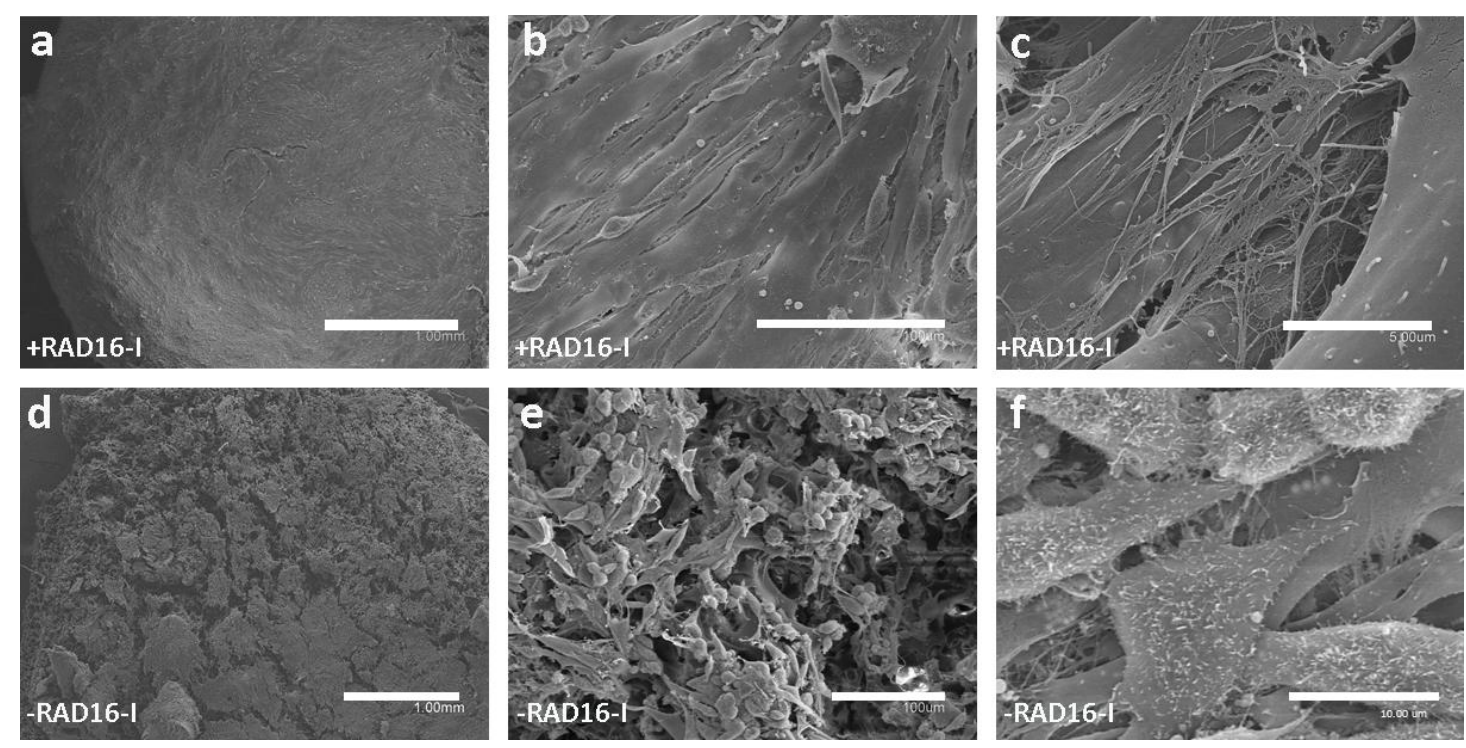

Figure 6: SEM images of the surface of cultured bare PEA scaffolds and composites. Overview of composite (a) and bare PEA (d) and close up of cultured surfaces of composites (b and c) and bare PEA (e and f). Scale bar represents $1 \mathrm{~mm}$ (a and d), $100 \mu \mathrm{m}$ (b and e), $10 \mu \mathrm{m}$ (c) and $5 \mu \mathrm{m}$ (f).

\subsection{Protein and gene profile of cells cultured in bare scaffolds and composites}

With the aim of characterizing subATDPCs growing in the scaffolds protein and gene expression of early and definitive cardiac markers were analyzed, using cells growing on two-dimensional (2D) PEA surfaces as controls.

Progenitor cells identity during early cardiogenesis is regulated by spatially and temporally well-organized pathways and mechanisms. In the course of differentiation, there is a progressive restriction of undifferentiated progenitors to the different lineages [47]. Although the mechanisms are not well understood, various transcription factors that may regulate cardiac commitment and differentiation were isolated in a definite stage of progenitor cell differentiation $[47,48]$. Here, the expression of early cardiac markers such as GATA4 (GATA binding protein 4), TBX5 (T-box transcription factor 5), NKX2.5 (NK2 homeobox 5), and MEF2C (Myocyte Enhancer Factor 2C); as well as some definitive cardiac markers such as ACTN1 ( $\alpha$-actinin), cTnT (Troponin T2, Tropomyosin-binding subunit in troponin complex), GJA1 (Gap Junction protein, alpha-1), and MHC (myosin, heavy chain) were examined. 

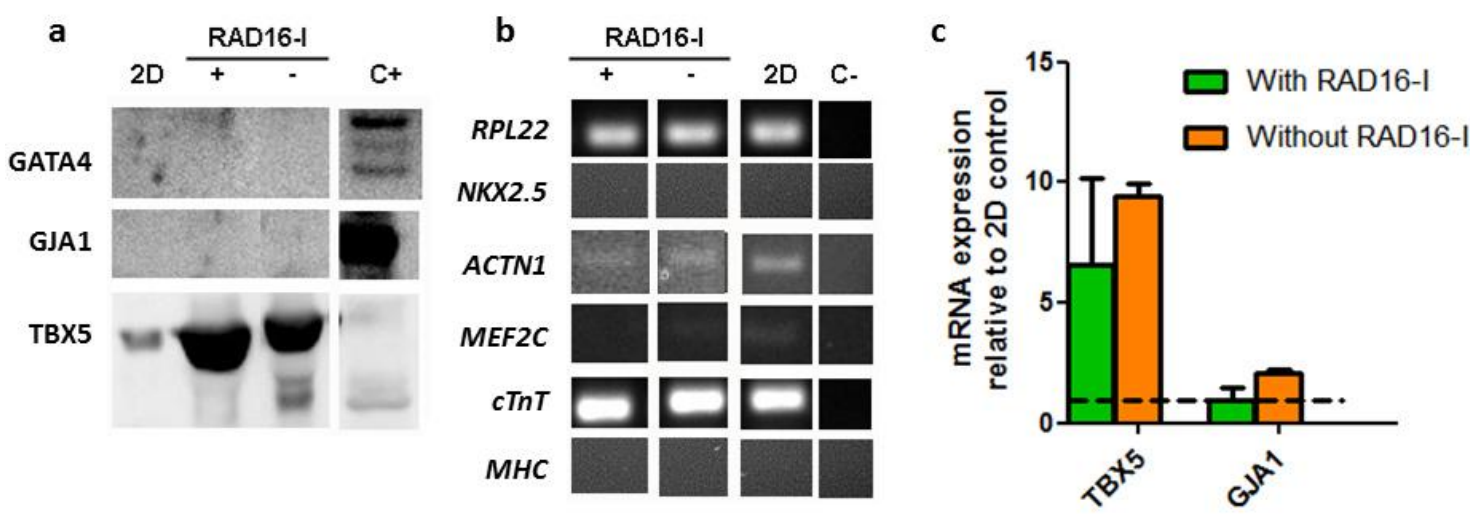

Figure 7: Protein and gene profile of cells cultured in bare PEA scaffolds and composites. a) Western blotting. Protein expression of cells cultured on 2D PEA compared to cells cultured in bare PEA scaffolds (RAD16-I -) and composites (RAD16-I +). C+ stands for the positive control for each protein. b) RT-PCR. Gene expression of cells cultured on 2D PEA compared to cells cultured in bare PEA scaffolds and composites. C- stands for the negative control used. c) qRT-PCR. The expression of TBX5 and GJA1 were assessed by Real Time RT-PCR experiments, establishing the base line through conventional monolayer cultures on PEA surfaces. No significant differences were observed between bare PEA and composites ( $p>0.05)$.

The expression of TBX5 early cardiac marker was found both at protein and gene level (Figure $7 \mathrm{a}$ and $\mathrm{c}$, respectively). Real time RT-PCR showed no significant $(\mathrm{p}>0.05)$ difference between subATDPCs cultured in bare PEA or in composites. This early cardiac marker is critical in heart development, and has been shown to interact with NKX2.5, GATA4 and MEF2C to synergistically activate target genes expression in cardiomyocytes [49]. A light band of $M E F 2 C$ was detected by RT-PCR (Figure 7b). This gene plays a key role in myogenesis [50] and has long been associated with the regulation of myocardial-expressed genes [51]. The expression of GATA4 and NKX2.5, also early cardiac markers, was not detected, which was not surprising at this early time point considering that at least 1 to 4 weeks have been reported to be needed for implanted mesenchymal stem cells to reach differentiation into cardiomyocytes within heart [52]. In addition, definitive cardiac markers were evaluated. GJA1, which is the major gap junction protein in the heart and therefore has a crucial role in the synchronized contraction, was analyzed at protein and gene level (Figure 7a and c). No significant ( $p>0.05)$ increase in gene expression (respect to $2 \mathrm{D}$ cultures) was detected by qRT-PCR (Figure 7c). Additionally, at protein level, GJA1 was not detected in any tested condition (Figure 7a). Moreover, MHC, ACTN1, and $c T n T$, at gene level were studied. MHC gene expression was not detected, but ACTN1 and $c T n T$ were identified (Figure 7b). Finally, ACTN1 expression was detected at gene and protein levels and cTnT at gene level in all conditions (Figure 7B and Figure 5). 


\section{DISCUSSION}

An efficient regenerative therapy for heart function recovery after myocardial infarction (MI) has not been yet outlined. The obstacle resides in the vast complexity of the heart muscle, where different factors at macroscopic and microscopic level such as heart contraction and cell connectivity, among others, must be taken into account to repair the damaged tissue. Although cell therapy appeared as an interesting approach, the conditions that remain after MI are not suitable for cell survival and proliferation. For this reason, the design and fabrication of biomaterials to be used as vehicles or even to give specific signaling to the cells are of great interest. These materials must be easy handling and cell-friendly, reproduce heart extracellular matrix, have sufficient mechanical stability and high porosity to lodge a high cell density, and do not produce an inflammatory response in vivo. Numerous polymers (natural and synthetic) have been widely investigated for cardiac tissue engineering, shaped in a variety of architectures [53-55]. These structures act as physical support for the seeded cells, allowing the exchange of oxygen and nutrients and removal of cellular secretions, to facilitate cell adhesion, survival, proliferation and differentiation [4]. On the other end, nanofibers in the form of self-assembling peptides emerged as a good system to better recreate a 3D environment [56]. Three-dimensional structures are essential for an appropriate spatial organization of cell surface receptors involved in cell-cell and cellECM interactions [57]. Here, a combination of PEA elastomeric membrane with RAD16-I self-assembling peptide is proposed and analyzed. PEA elastomeric membrane fulfills many of the essential characteristics prescribed for necrotic myocardium repair, but it fails to emulate the cardiac tissue at the nano-scale. The peptide gel network provided by RAD16-I resembles ECM environment and has been shown to increase growth and cellular proliferation of different cell types. However, the RAD16-I poor mechanical properties are an important drawback for its implantation in the continuous beating heart [58]. Therefore, the combination of this soft material with synthetic polymeric materials with improved elasticity and tensile strength arise as an interesting approach. Both materials would contribute to the implant success at different levels: the polymeric elastomeric membrane would be responsible for providing an adequate physical support, whereas the natural gel would confer an in vivo-like environment to the cells. 
In this study, subATDPCs viability, growth, mobilization and progenitor phenotype maintenance in PEA elastomeric membrane filled with peptide gel (composites) was assessed in vitro. The bioactive patch developed presents a good advantage as a cell vehicle for cell therapies. It has been demonstrated by MTT analysis that cells can proliferate within this milieu to a five-fold increase after 10 days of in vitro culture, and similarly in bare scaffolds $(\mathrm{p}<0.001)$. The gel works as cell diffusion medium, facilitating the invasibility of the scaffold's pores upon seeding and after 10 days both the polymeric surface and the inner trabeculae were covered with cells [42]. In the composites, subATDPCs completely covered the surface of the scaffolds and adopted an elongated shape, contacting one to each other. However, expression of GJA1 was not detected, which means that, at this time point, the cell-cell connectivity for low molecular weight molecules diffusivity was not assembled [59]. In bare scaffolds, cells remain adhered on the PEA trabeculae and arrange forming circumferences, rather than occupying the 'empty' pores. The well-known outstanding cell adhesion and biological performance of PEA hinders though cell migration to the surface of the patch $[34,42]$. The main advantaged of the composite resides in the capacity of promoting cell mobilization outwards, which could facilitate cell grafting at the affected site.

subATDPCs (MSC-like) were used in this work due to their cardiogenic potential lineage. It was the primary aim to ensure that these cells in the proposed biomaterials (bare PEA or the composite) did not alter their genetic profile. As described, subATDPCs preserved their cardiogenic potential lineage by the expression of early cardiac markers such as TBX5 and MEF2C or definitive markers such as ACTN1 and $c T n T$. No significant differences in gene or protein expression between the cells cultured in composites, bare scaffolds and controls. TBX5 early cardiac marker is critical in heart development, and it has been reported to regulate the activity of other genes by attaching to specific regions of DNA [49]. It has also been shown to interact with NKX2.5, GATA4 and MEF2C to synergistically activate target genes expression in cardiomyocytes [49]. MEF2C expression, which plays a key role in myogenesis, has been related with the expression of genes such as ACTN1 and MHC. In terms of definitive cardiac markers, ACTN1 is a marker of mature cardiomyocytes that helps to anchor the myofibrillar actin filaments. It is the major component of the contractile apparatus [60]. cTnT, a constituent of the troponin complex, which connects the troponin complex to tropomyosin regulating muscle contraction in response to alteration 
in intercellular calcium concentration, was also detected. This complex controls the calcium mediated interaction between actin and myosin. In contrast with other multigene families, the skeletal and cardiac proteins of this complex are not derived from alternative splicing of exons from a single gene [61]. Therefore, they have, theoretically, the potential of being unique to the myocardium. This led us to hypothesize that subATDPCs would be able to differentiate towards a cardiac-like phenotype. Although these results are not conclusive to resolve a differentiation toward a cardiac phenotype, we observe that subATDPCs maintain their phenotype after 10 days of culture in both bare PEA and the composite. Therefore, we think that this biomaterial is not cardioconductive but is able to preserve cell potentiality, which could facilitate their lineage commitment. Further analysis at longer time points and using different kind of induction (chemical or physical) would be important to elucidate possible cardiac differentiation at more definitive stages. Therefore, it was concluded that the PEA elastomeric scaffold, with or without RAD16-I gel in the pores, is a noninductive milieu where subATDPCs can survive, grow and mobilize after implantation at the ischemic tissue.

\section{CONCLUSIONS}

The high complexity found in heart tissue makes it impossible to find a unique material that fulfills all the needed requirements to regenerate infarcted tissue. In this study we demonstrate the benefits provided by the combination of two synthetic biomaterials with really different properties. This combination allows obtaining a biomaterial with proper mechanical properties and verified suitable microenvironment for cell culture. RAD16-I was introduced inside the PEA elastomeric membrane pores with the aim of creating a milieu that can imitate more properly the in vivo environment. Additionally, it was pretended to improve cell adhesion following the preparation of the bioactive implant and promote cell proliferation over time [34]. The final intention of the bioactive implant proposed is to be implanted on an ischemic heart, and it is hoped that it helps to maintain the seeded cells in the affected area, which would increase their effect. The improved cell diffusion through the peptide in the pores suggests that when implanted in an in vivo model of $\mathrm{MI}$, the grafted cells would be able to migrate towards the necrotic cardiac tissue. On the contrary, whether the pre-seeded bare scaffold was implanted, cells would preferably remain within the pores. It is expected that after 
implantation of the developed patch, cells would be able to migrate towards the necrotic zone, producing some paracrine effect [62] and stimulate tissue regeneration.

\section{ACKNOWLEDGMENTS}

The authors wish to thank the Department of Cardiac Surgery (Hospital Germans Trias i Pujol, Badalona, Spain) for their collaboration in obtaining human samples. The research leading to these results has received funding from the European Union Seventh Framework Programme (FP7/2007-2013) under grant agreement nº 229239. 


\section{REFERENCES}

1. Persidis A. Tissue engineering. Nat Biotechnol. 1999;17:508-10.

2. Castells-Sala C, Alemany-Ribes M, Fernández-Muiños T, Recha-Sancho L, López-Chicón P, Aloy-Reverté C, et al. Current Applications of Tissue Engineering in Biomedicine. Biochips and Tissue Chips. 2013;0-14.

3. Venugopal JR, Prabhakaran MP, Mukherjee S, Ravichandran R, Dan K, Ramakrishna S. Biomaterial strategies for alleviation of myocardial infarction. J R Soc Interface. 2012; 9(66):1-19.

4. Castells-Sala C, Semino CE. Biomaterials for stem cell culture and seeding for the generation and delivery of cardiac myocytes. Curr Opin Organ Transplant. 2012;17(6):681-7.

5. Nunes SS, Song H, Chiang CK, Radisic M. Stem cell-based cardiac tissue engineering. J Cardiovasc Transl Res. 2011;4(5):592-602.

6. Fernandes S, Kuklok S, McGonigle J, Reinecke H, Murry CE. Synthetic matrices to serve as niches for muscle cell transplantation. Cells Tissues Organs. 2012 ;195(1-2):48-59.

7. Hoover-Plow J, Gong Y. Challenges for heart disease stem cell therapy. Vasc Health Risk Manag. 2012;8:99-113.

8. Abdelli LS, Merino H, Rocher CM, Singla DK. Cell therapy in the heart. Can J Physiol Pharmacol. 2012;315:307-15.

9. Rane A a, Christman KL. Biomaterials for the treatment of myocardial infarction a 5-year update. J Am Coll Cardiol. 2011;58(25):2615-29.

10. Karam J-P, Muscari C, Montero-Menei CN. Combining adult stem cells and polymeric devices for tissue engineering in infarcted myocardium. Biomaterials 2012;33(23):5683-95.

11. Clifford DM, Fisher SA, Brunskill SJ, Doree C, Mathur A, Clarke MJ, et al. Long-term effects of autologous bone marrow stem cell treatment in acute myocardial infarction: factors that may influence outcomes. PLoS One. 2012;7(5):e37373.

12. Lee R, Kim B, Choi I, Kim H, Choi H, Suh K, et al. Characterization and expression analysis of mesenchymal stem cells from human bone marrow and adipose tissue. Cell Physiol Biochem. 2004;14:311-24.

13. Qayyum AA, Haack-Sørensen M, Mathiasen AB, Jørgensen E, Ekblond A, Kastrup J. Adipose-derived mesenchymal stromal cells for chronic myocardial ischemia (MyStromalCell Trial): study design. Regen Med. 2012 ;7(3):421-8. 
14. Bai X, Ma J, Pan Z, Song Y-H, Freyberg S, Yan Y, et al. Electrophysiological properties of human adipose tissue-derived stem cells. Am J Physiol Cell Physiol. 2007;293(5):C1539-50.

15. Tandon N, Goh B, Marsano A, Chao P-HG, Montouri-Sorrentino C, Gimble J, et al. Alignment and elongation of human adipose-derived stem cells in response to direct-current electrical stimulation. Conf Proc IEEE Eng Med Biol Soc. 2009:6517-21.

16. Rigol M, Solanes N, Farré J, Roura S, Roqué M, Berruezo A, et al. Effects of adipose tissue-derived stem cell therapy after myocardial infarction: impact of the route of administration. J Card Fail. 2010;16(4):357-66.

17. Planat-Bénard V, Menard C, André M, Puceat M, Perez A, Garcia-Verdugo J-M, et al. Spontaneous cardiomyocyte differentiation from adipose tissue stroma cells. Circ Res. 2004;94(2):223-9.

18. Weber B, Zeisberger SM, Hoerstrup SP. Prenatally harvested cells for cardiovascular tissue engineering: fabrication of autologous implants prior to birth. Placenta. 201;32 Suppl 4:S316-9.

19. Cortes-Morichetti M, Frati G, Schussler O, Van Huyen J-PD, Lauret E, Genovese JA, et al. Association between a cell-seeded collagen matrix and cellular cardiomyoplasty for myocardial support and regeneration. Tissue Eng. 2007;13(11):2681-7.

20. Shafy A, Fink T, Zachar V, Lila N, Carpentier A, Chachques JC. Development of cardiac support bioprostheses for ventricular restoration and myocardial regeneration. Eur J Cardiothorac Surg. 2012;0(6):1-9.

21. Chi N, Yang M, Chung T, Chen J, Chou N, Wang S. Cardiac repair achieved by bone marrow mesenchymal stem cells/silk fibroin/hyaluronic acid patches in a rat of myocardial infarction model. Biomaterials. 2012;33:5541-51.

22. Wang T, Jiang X, Tang Q, Li X, Lin T, Wu D, et al. Bone marrow stem cells implantation with alpha-cyclodextrin/MPEG-PCL-MPEG hydrogel improves cardiac function after myocardial infarction. Acta Biomater. 2009;5:2939-44.

23. Wu J, Zeng F, Huang X, Chung J, Konecny F, Weisel R, et al. Infarct stabilization and cardiac repair with a VEGF-conjugated, injectable hydrogel. Biomaterials. 2011;32(2):579-86.

24. Vunjak-Novakovic G, Lui KO, Tandon N, Chien KR. Bioengineering heart muscle: a paradigm for regenerative medicine. Annu Rev Biomed Eng. 2011 Aug $15 ; 13: 245-67$.

25. Dobner S, Bezuidenhout D, Govender P, Zilla P, Davies N. A synthetic nondegradable polyethylene glycol hydrogel retards adverse post-infarct left ventricular remodeling. J Card Fail. 2009;15(7):629-36. 
26. Blan NR, Birla RK. Design and fabrication of heart muscle using scaffold-based tissue engineering. J Biomed Mater Res. 2008;86A:195-208.

27. Zhao X, Zhang S. Self-assembling nanopeptides become a new type of biomaterial. Advances in Polymer Science. 2006. p. 145-70.

28. Arnal-Pastor M, Vallés-Lluch A, Keicher M, Monleón Pradas M. Coating typologies and constrained swelling of hyaluronic acid gels within scaffold pores. J Colloid Interface Sci. 2011;361(1):361-9.

29. Pérez Olmedilla M, Garcia-Giralt N, Pradas MM, Ruiz PB, Gómez Ribelles JL, Palou EC, et al. Response of human chondrocytes to a non-uniform distribution of hydrophilic domains on poly (ethyl acrylate-co-hydroxyethyl methacrylate) copolymers. Biomaterials. 2006;27(7):1003-12.

30. Soria M, Marti C, Salmero M, Benavent V, Go L, Garci M, et al. Survival and differentiation of embryonic neural explants on different biomaterials. J Biomed Mater Res Part A. 2006;79:495-502.

31. Campillo-Fernandez AJ, Pastor S, Abad-Collado M, Bataille L, Gomez-Ribelles JL, Meseguer-Dueñas JM, et al. Future design of a new keratoprosthesis. Physical and biological analysis of polymeric substrates for epithelial cell growth. Biomacromolecules. 2007;8(8):2429-36.

32. Martínez Ramos C, Vallés-Lluch A, Verdugo JMG, Ribelles JLG, Barcia Albacar JA, Orts AB, et al. Channeled scaffolds implanted in adult rat brain. J Biomed Mater Res A. 2012;100(12):3276-86.

33. Rodríguez Hernández JC, Salmerón Sánchez M, Soria JM, Gómez Ribelles JL, Monleón Pradas M. Substrate chemistry-dependent conformations of single laminin molecules on polymer surfaces are revealed by the phase signal of atomic force microscopy. Biophys J. 2007;93(1):202-7.

34. Vallés-Lluch A, Arnal-Pastor M, Martínez-Ramos C, Vilariño-Feltrer G, Vikingsson L, Castells-Sala C, et al. Combining self-assembling peptide gels with three-dimensional elastomer scaffolds. Acta Biomater. 2013;9:9451-60.

35. Kisiday J, Jin M, Kurz B, Hung H, Semino C, Zhang S, et al. Self-assembling peptide hydrogel fosters chondrocyte extracellular matrix production and cell division : implications for cartilage tissue repair. Proc Natl Acad Sci U S A. 2002;99(15):9996-10001.

36. Semino CE, Merok JR, Crane GG, Panagiotako G, Zhang S. Functional differentiation of hepatocyte-like spheroid structures from putative liver progenitor cells in three-dimensional peptide scaffolds. Differentiation. 2003;(71):262-70.

37. Narmoneva DA, Vukmirovic R, Davis ME, Kamm RD, Lee RT. Endothelial Cells Promote Cardiac Myocyte Survival and Spatioal Reorganization: implications for Cardiac Regeneration. Circ Res. 2009;110(8):962-8. 
38. Genové E, Shen C, Zhang S, Semino CE. The effect of functionalized selfassembling peptide scaffolds on human aortic endothelial cell function. Biomaterials. 2005;26:3341-51.

39. Ellis-behnke RG, Liang Y, You S, Tay DKC, Zhang S, So K, et al. Nano neuro knitting: Peptide nanofiber scaffold for brain repair and axon regeneration with functional return of vision. PNAS. 2006;103(13):5054-9.

40. Garreta E, Genové E, Borrós S, Semino CE. Osteogenic differentiation of mouse embryonic stem cells and mouse embryonic fibroblasts in a three-dimensional self-assembling peptide scaffold. Tissue Eng. 2006;12(8):2215-27.

41. Quintana L, Fernandez Muiños T, Genove E, Olmos MDM, Borros S, Semino CE. Early Tissue Patterning Recreated by Mouse Embryonic Fibroblasts in a Three-Dimensional Environment. Tissue Eng. 2009;15(1):45-54.

42. Martínez-Ramos C, Rodríguez-Pérez E, Garnes MP, Chachques JC, Moratal D, Vallés-Lluch A, et al. Design and Assembly Procedures for Large-Sized Biohybrid Scaffolds as Patches for Myocardial Infarct. Tissue Eng Part C Methods. 2014; 20(10):817-27

43. Brígido Diego R, Pérez Olmedilla M, Serrano Aroca A, Gómez Ribelles JL, Monleón Pradas M, Gallego Ferrer G, et al. Acrylic scaffolds with interconnected spherical pores and controlled hydrophilicity for tissue engineering. J Mater Sci Mater Med. 2005;16(8):693-8.

44. Diego R, Estellés J, Sanz J, García-Aznar J, Sánchez M. Polymer scaffolds with interconnected spherical pores and controlled architecture for tissue engineering: fabrication,mechanical properties, and finite element modeling. J Biomed Mater Res B Appl Biomater. 2007;81:448-55.

45. Bayes-Genis A, Soler-Botija C, Farré J, Sepúlveda P, Raya A, Roura S, et al. Human progenitor cells derived from cardiac adipose tissue ameliorate myocardial infarction in rodents. $\mathrm{J}$ Mol Cell Cardiol. Elsevier Ltd; 2010;49(5):771-80.

46. Martinez-Estrada O, Munoz-Santos Y, Julve J, Reina M, Vilaro S. Human adipose tissue as a source of Flk-1+ cells: new method of differentiation and expansion. Cardiovasc Res [Internet]. 2005 Feb 1 [cited 2013 Apr 5];65(2):32833. Available from: http://www.ncbi.nlm.nih.gov/pubmed/15639471

47. Cyganek L. Cardiac Progenitor Cells and their Therapeutic Application for Cardiac Repair. J Clin Exp Cardiolog. 2013;01(S11).

48. Horb ME, Thomsen GH. Tbx5 is essential for heart development. Development. 1999;126(8):1739-51.

49. Wang C, Cao D, Wang Q, Wang D-Z. Synergistic activation of cardiac genes by myocardin and Tbx5. PLoS One. 2011;6(8):e24242. 
50. Wilson-Rawls J, Molkentin JD, Black BL, Olson EN. Activated Notch Inhibits Myogenic Activity of the MADS-Box Transcription Factor Myocyte Enhancer Factor 2C. Mol. Cell. Biol. 1999; 19(4):2853

51. Lockhart MM, Wirrig EE, Phelps AL, Ghatnekar A V, Barth JL, Norris R a, et al. Mef2c regulates transcription of the extracellular matrix protein cartilage link protein 1 in the developing murine heart. PLoS One. 2013;8(2):e57073.

52. Jiang W, Ma A, Wang $\mathrm{T}$, Han K, Liu Y, Zhang $\mathrm{Y}$, et al. Homing and differentiation of mesenchymal stem cells delivered intravenously to ischemic myocardium in vivo: a time-series study. Pflugers Arch. 2006;453(1):43-52.

53. Prabhakaran M, Venugopal J, Kai D and Ramakrishna S. Biomimetic material strategies for cardiac tissue engineering. Mat Sci Eng C. 2011;31(3):503e13.

54. Xu B, Li Y, Fang X, Thouas GA, Cook WD, Newgreen DF, et al. Mechanically tissue-like elastomeric polymers and their potential as a vehicle to deliver functional cardiomyocytes. J Mech Behav Biomed Mater. 2013;28:354-65.

55. Zhou J, Shu Y, Lü S-H, Li J-J, Sun H-Y, Tang R-Y, et al. The spatiotemporal development of intercalated disk in three-dimensional engineered heart tissues based on collagen/matrigel matrix. PLoS One. 2013;8(11):e81420.

56. Zhang S, Gelain F, Zhao X. Designer self-assembling peptide nanofiber scaffolds for 3D tissue cell cultures. Semin Cancer Biol. 2005;15(5):413-20.

57. Santos E, Hernández RM, Pedraz JL, Orive G. Novel advances in the design of three-dimensional bio-scaffolds to control cell fate: translation from $2 \mathrm{D}$ to $3 \mathrm{D}$. Trends Biotechnol. 2012;30(6):331-41.

58. Dégano IR, Quintana L, Vilalta M, Horna D, Rubio N, Borrós S, et al. The effect of self-assembling peptide nanofiber scaffolds on mouse embryonic fibroblast implantation and proliferation. Biomaterials. 2009;30(6):1156-65.

59. Kanno S, Saffitz JE. The role of myocardial gap junctions in electrical conduction and arrhythmogenesis. Cardiovasc Pathol. 2001;10(4):169-77.

60. The Weizmann Science of. Gene Cards. http://www.genecards.org/ (25/10/14).

61. Messner B, Baum H, Fischer P, Quasthoff S, Neumeier D. Expression of messenger RNA of the cardiac isoforms of troponin $\mathrm{T}$ and $\mathrm{I}$ in myopathic skeletal muscle. Am J Clin Pathol. 2000;114(4):544-9.

62. Gnecchi M, Danieli P, Cervio E. Mesenchymal stem cell therapy for heart disease. Vascul Pharmacol. 2012;57(1):48-55. 